\title{
BIOCHEMICAL CHANGES IN HEROIN ADDICTS
}

\author{
K. BALASUBRAMANIAM*, VASANTHY ARASARATNAM, SAMANTHY \\ NADARAJAH, MARY SORUBINY CHELLIAH, P. LAKSHMAN AND PK. \\ ARULAMPALAM \\ Department of Biochemistry, Faculty of Medicine, University of Jaffna, Kokuvil.
}

(Date of receipt $: 15$ February 1993)
(Date of acceptance $: 13$ January 1994)

\begin{abstract}
Thirty heroin addicts and thirty non-addicts from the Jaffna Municipality and suburbs were chosen randomly. All the selected subjects were males and the mean ages of addicts and non-addicts were $33.4( \pm 4.4 \mathrm{SD})$ years and $30.9( \pm 3.9)$ years respectively. Of the addicts $70 \%$ took heroin by smoking. Addicts had taken 187.5 ( \pm 89.4$) \mathrm{mg}$ heroin, four times $( \pm 0.88$ ) a day and had been using this drug for at least $3.2( \pm 2.0$ ) years. There were no significant difference between body weights and blood pressures of addicts and non-addicts. A modified glucose tolerance test showed that the mean blood glucose levels were significantly increased in the addicts. Mean serum free fatty acid levels and the mean ratio of serum total cholesterol to HDL cholesterol were significantly higher in addicts than non-addicts? Likewise the serum aspartate transaminase (AST) and serum alanine transaminase (ALT) levels of addicts were significantly higher than in the non-addicts.
\end{abstract}

Key words: Heroin, addicts, glucose tolerance, serum lipids, enzymes.

\section{INTRODUCTION}

The large quantities of opium and heroin being seized in neighbouring countries indicate the existence of extensive illicit poppy cultivation and a substantial heroin manufacturing capacity. The increasing traffic in heroin and its ready availability has led to an escalation of the abuse of this drug in many parts of the Asia including Sri Lanka. Opium, its constituents and derivatives are widely used in medicine as analgesics to relieve pain and induce sleep. ${ }^{1}$ Heroin is a narcotic, derived from opium. Heroin addiction has become a serious world-wide problem. Deaths due to heroin addiction are génerally due to secondary causes such as infection, allergic reactions ${ }^{3}$ and the drug over dosage. ${ }^{2}$ Liver damage due to hepatitis is also reported when heroin is regularly taken a few times a day in small doses. ${ }^{2}$ Heroin is rapidly changed in the body to monoacetyl morphine and morphine. ${ }^{1}$ Its quick action is attributed to its solubility, which allows rapid passage through the blood brain barrier into brain. This brings about the desired pain killing effect and associated relaxation relief from anxiety. Apart from such physiological changes, the heroin might be expected to bring about biochemical changes. We report here on the glucose tolerance, the ratio of total cholesterol and HDL cholesterol, the level of free fatty acid in the serum and the activities of serum aspartate transaminase (AST) and serum alanine transaminase (ALT) in heoin addicts. 


\section{METHODS AND MATERIALS}

\section{Subjects}

Thirty heroin addicts and thirty non-addicts aged between 28 and 38 y were selected irom Jaffna and its suburbs. A questionnaire was prepared and necessary details were collected by the interviewer (Table 1).

\section{Trbie 1: Questionnaire}

1. Age.

2. Weight.

3. History of the drug habit.

3.1 How first introduced?

3.2 Duration of addiction.

3.3 Mode of intake (smoking/inhaling/intravenous)

3.4 Daily dosage.

4. Other habits (smoking, alcoholism etc.).

5. Complications, previous or present.

(Hepatic jaundice, angina pectoris, neural disorders etc.)

6. Blood pressure.

\section{Analytical methods}

Standard methods were used to estimate serum HDL cholesterol, ${ }^{4}$ total cholesterol ${ }^{4}$ and free fatty acid ${ }^{4}$ and activities of $\mathrm{AST}^{5}$ and $\mathrm{ALT}^{5}$ A modified glucose tolerance test was performed by collecting blood samples at zero, one and two hours. ${ }^{4}$ Blood pressure was recorded by mercurical sphygmomanometer.

\section{Statistical analysis}

Significance of the difference between two means was determined by the Student's ' $t$ ' test.

\section{RESULTS AND DISCUSSION}

The subjects selected from the Jaffna municipality limits and its suburbs were all males and the addicts and non-addicts had a mean age of $33.4( \pm 4.4)$ years and 30.9 $( \pm 3.9)$ years respectively (Table 2 ). The addicts took 187.5 ( \pm 89.4$) \mathrm{mg}$ of heroin, $4( \pm 0.88)$ times a day. Previous report indicates that the average daily consumption of heroin is $500 \mathrm{mg}$ per day. 3,6 The mean period of drug addiction of the selected subjects was $3.2( \pm 2.0)$ years. A majority of addicts studied took heroin by smoking (70\%) while $23.3 \%$ took it intravenously and $6.7 \%$ by inhalation. The most favoured route of administration in Sri Lanka was earlier reported to be inhalation (87\%). ${ }^{6}$

\pm Standard deviations are reported within parentheses. 
Table 2: Mean age, weight and blood pressure of heroin addicts and non-addicts.

\begin{tabular}{|c|c|c|c|}
\hline Subject & $\begin{array}{l}\text { Age } \\
\text { (Years) }\end{array}$ & $\begin{array}{l}\text { Weight } \\
\text { (kg) }\end{array}$ & $\begin{array}{c}\text { Blood pressure } \\
\text { SBP/DBP } \\
\text { (mm Hg) }\end{array}$ \\
\hline Addicts & $33.4( \pm 4.4)$ & $54.3( \pm 4.2)$ & $123( \pm 8.5) / 77.8 \quad( \pm 9.4)$ \\
\hline Non-addicts & $30.9( \pm 3.9)$ & $55.5( \pm 6.8)$ & $121( \pm 8.2) / 77 \quad( \pm 6.6)$ \\
\hline
\end{tabular}

The standard deviations are given in parentheses. Difference between the main weights of addicts and non-addicts is not significant $(p<0.05, t=0.8)$.

A modified glucose tolerance test was performed in heroin addicts and non-addicts. In these subjects the blood was collected at 0,1 and $2 \mathrm{~h}$ instead of the normal half an hour interval. In both addicts and non-addicts, the $2 \mathrm{~h}$ blood glucose levels were lower than those at zero time (Table 3). However the difference in the mean blood glucose levels of addicts and non-addicts at 0,1 and $2 \mathrm{~h}$ were statistically significant $\mathrm{p}<0.01,(t=8.7,14.9$ and 10.2 respectively $)$. The increased blood glucose levels in the addicts could be due to increased levels of catecholamines ${ }^{7}$ leading to enhanced glycogenolysis and gluconeogenesis. ${ }^{8}$ The addicts were of the same age group as the non-addicts, had the same body weight and showed no significant difference in blood pressures (Table 2). Thus the difference in glucose tolerance could not be due to age or other effects. The mean blood glucose levels of the addicts at $1 \mathrm{~h}$ was $175( \pm 16.6) \mathrm{mg} \mathrm{dl}^{-1}$, which is close to the tubular maximum value. However none of the addicts excreted glucose in urine.

Table 3: Glucose tolerance in heroin addicts and non-addicts.

\begin{tabular}{lccc} 
& \multicolumn{3}{c}{$\begin{array}{c}\text { Blood glucose } \\
\left(\mathrm{mg} \mathrm{dl}^{-1}\right)\end{array}$} \\
& 0 & 1 & 2 \\
& $($ hour $)$ & (hour) & $119.9( \pm 22.4)$ \\
& $122.0( \pm 22.7)$ & $175.0( \pm 16.6)$ & $73.4( \pm 10.8)$ \\
\hline Addicts & $82.1( \pm 11.0)$ & $123.1( \pm 9.5)$ & (hour) \\
\hline
\end{tabular}

Standard deviations are given in parentheses. The difference in the mean blood glucose levels of addicts and non-addicts were statistically significant $(p<0.01, t=8.7,14.9$ and 10.2 repectively).

Mean ratios of the total cholesterol to HDL cholesterol levels of addicts and non-addicts were $4.8( \pm 2.1)$ and $3.6( \pm 0.9)$ respectively (Table 4). The difference between the ratios of addicts and non-addicts was statistically significant $(\mathrm{p}<0.01$, $t=2.8$ ). Thus it implies that the HDL cholesterol level in the drug addicts is less than that in non-addicts. The decrease in HDL cholesterol is a significant indication 
for the chances of getting coronary heart diseases. ${ }^{8}$ In support to this observation, the difference in mean serum free fatty acid levels of drug addicts and non-addicts (rable 4) was statistically significant $($ S.E. $=6.0)$. The increased circulatory free fatty acid entering the liver leads to the synthesis and secretion of more triacylglycerol $^{8}$ which in turn may increase the cholesterol synthesis and this is reflected in the increased ratio of total cholesterol to $\mathrm{HDL}$ cholesterol. Our previous work (unpublished) also indicated that the serum total cholesterol and triacylglycerol levels.were significantly elevated in heroin addicts. Heroin through its metabolite morphine increases cAMP levels either directly ${ }^{7}$ or through growth hormone ${ }^{7}$ and catecolamine ${ }^{7}$ and causes break down of triacylglycerol in the adipose tissue, which results in increased serum free fatty acid and glycerol levels. Elevated levels of LDL cholesterol and serum free fatty acid cannot be attributed to the nutritional status of the addicts as the mean body weights of addicts and non-addicts were not significantly different, $(\mathrm{p}>0.05, \mathrm{t}=0.8)$ (Table 2$)$.

To evaluate the toxicity of heroin, serum aspartate transaminase (AST) and alanine transaminase (ALT) activities were measured. The AST and ALT activities in heroin addicts were significantly ( $\mathrm{p}<0.01, \mathrm{t}=7.7$ and 6.4 respectively) higher in addicts (Table 5). The elevated transaminase levels suggest that heroin is toxic.

Table 4: Ratios of serum total cholesterol to HDL cholesterol and serum free fatty acid levels in heroin addicts and non-addicts.

Total cholesterol

Subject

Serum free fatty acid

HDL cholesterol $\quad\left(\mu \mathrm{mol} 1^{-1}\right)$

\begin{tabular}{lll}
\hline Addicts & $4.8( \pm 2.1)$ & $987.6( \pm 286.3)$ \\
Non-addicts & $3.6( \pm 0.9)$ & $661.7( \pm 90.6)$
\end{tabular}

The standard deviations are given in parentheses. The difference between the mean ratios of total cholestero! to HIDL cholesterol levels and the serum free fatty acid levels of addicts and non-addicts were significantly different $(p<0.01, t=2.8$ and 6.8 respectively).

Table 5: Mean AST and ALT activities of addicts and non-addicts

\section{Activity (IU $1^{-1}$ )}

Subject AST ALT

$\begin{array}{lll}\text { Addicts } & 67.8( \pm 28.8) & 80.8( \pm 46.0) \\ \text { Non-addicts } & 23.9( \pm 12.1) & 26.5( \pm 8.4)\end{array}$

The standard deviations are given in parentheses. The difference between the means of AST and ALT of addicts and non-addicts were significantly different $(p<0.01, t=7.7$ and 6.4 respectively). 


\section{Acknowledgement}

The authors thank the subjects for coorperation, and the technical staff of the Department of Biochemistry for assistance.

\section{References}

1. Robertson R. (1987). Heroin AIDS and Society. pp. 30-34. London Hodder and Stoughton, London.

2. Abelson P.H. (1970). Death from heroin. Science 168:1289.

3. Rossi G.V. (1975). Pharmacological aspects of drug abuse. Remingtons Pharmaceutical Science. (Ed. J.E. Hoover) (15th ed.) pp. 1287. Mack Publishing Company, Pennsylvania.

4. Varley H., Gowenlock A.H. \& Bell M. (1980). Practical Clinical Biochemistry. Vol. 1 (5th ed), William Heinemann Medical Books Ltd., London.

5. Wotton J.D.P. (1964). Micro Analysis in Medical Biochemistry, (4th ed), J \& A Churchill Ltd., London.

6. Illicit drug trafficking and drug abuse in Sri Lanka (1986). National Dangerous Drugs Control Board, Colombo. pp. 6-7.

7. Gannong F.W. (1983). Review of Medical Physiology. (12th ed) pp. 235 - 336, Language Medical Publications, Maruzen Co. Ltd., USA.

8. Murray R.K., Mayes P.A., Granner D.K. \& Rodwell V.W. (1990). Harper's Biochemistry. (22nd ed), Connecticute, Prentine-Hall International Inc. 